\title{
Evaluation of Cold Tolerance among Japanese Persimmon 'Saijo' Strains
}

\author{
Keisuke MOCHIDA*i, and Hiroyuki ITAMURA** \\ $\left.\begin{array}{c}* \text { Shimane Agricultural Technology Center, Izumo, Shimane 693-0035 } \\ * * \text { Faculty of Life and Environmental Science, Shimane University, Matsue, Shimane 690-0823 }\end{array}\right)$
}

\begin{abstract}
Cold tolerance was compared among the three 'Saijo' persimmon strains "Abe", "Endo", and "Izumo". We also determined the carbohydrate and non-tannin flavans content (mainly anthocyanins) in the stems and buds of 1-year-old twigs of the three strains. In "Abe", the total sugar content in stems in early spring, just before sprouting, was significantly lower than those of "Endo" and "Izumo". This was because the amounts of sucrose and sorbitol contained in "Abe" were significantly lower than those in the other two strains. The glucose content of "Abe" buds in early spring was likewise significantly lower than that of the other two strains. The non-tannin flavan contents of the buds and bark tissues of "Abe" stems were lower than those of "Endo", while in mid-March the electrolyte leakage of stems and buds of "Abe" during treatments at -3 and $-6^{\circ} \mathrm{C}$ was found to be significantly higher than in the other two strains. Browning was observed in "Abe" on stems after treatment at $-3^{\circ} \mathrm{C}$, and on cambiums after treatment at $-6^{\circ} \mathrm{C}$. Our results showed that "Abe" is the least tolerant to cold among the three strains. The sprouting disorders frequently observed in "Abe" may result from slight freezing injuries to buds.
\end{abstract}

Key words: Anthocyanin, Flavan, Freezing injury, Sugar.

\section{Introduction}

The Japanese persimmon (Diospyros kaki) cultivar 'Saijo' consists of many different strains, which differ in terms of their fruit shapes and ripening periods. These strains are distributed throughout the Chugoku districts, Hiroshima (the origin of 'Saijo') and its surroundings, Okayama, Tottori, Shimane, and Yamaguchi. The genetic variations have arisen due to bud mutations.

The Shimane Prefecture Agricultural Experiment Station selected 6 desirable early-ripening 'Saijo' strains from more than 10 strains cultivated in Shimane: "Abe", "Endo", "B-dwarf" (a dwarf strain of "Endo"), "Yamasaka", "Koto", and "Wada". These strains were classified as "B-type" persimmons based on their fruit shapes (obovate with four deep grooves) and fruit ripening time (harvestable from early October)

Received; December 20, 2007.

Accepted; September 30, 2008

${ }^{\dagger}$ Corresponding author: mochida-keisuke@pref.shimane. lg.jp
(Kono et al., 1980). However, apparent differences were observed in the tree growth and fruit productivity among the six strains, and "Endo" was selected as an elite line (Mochida et al., 2007). "Abe" in particular had relatively poor fruit productivity and frequent physiological disorders, such as a delayed sprouting period, decreased sprouting rate, and poor shoot elongation. Together, these physiological attributes resulted in a decreased leaf count and leaf area index in "Abe".

Late frost damage in persimmons causes tree decline, while browning disorders on sprouts can be caused by late frosts. These can occur in orchards located in hollows or valleys, where frost protection instruments such as wind machines are not used. Frost injury appears at -1.5 to $-2.0^{\circ} \mathrm{C}$ at sprouting time in almost all persimmon cultivars (Kikuchi, 1991). The 'Saijo' strain sprouts in early- to late-March in Shimane. The minimum temperature at the persimmon orchards in Shimane prefecture occasionally drops below zero at this time of year, hence the cold tolerance of buds and stems during this period is important for initial tree growth and productivity.

In this study, we investigated the carbohydrate 
contents and cold tolerance of buds and stems of three 'Saijo' strains. Twig cold tolerance was reportedly improved by increased non-tannin flavan content (mainly anthocyanins) during cold acclimation in persimmon, apple, and peach (Leng et al., 1997; Leng et al., 2000). Therefore, we investigated the non-tannin flavan contents in these 'Saijo' strains.

\section{Materials and Methods}

\subsection{Plant Material}

The experiment was conducted at the Masuda Branch of the Shimane Agricultural Experiment Station $\left(131^{\circ} 51^{\prime} \mathrm{E}, 34^{\circ} 40^{\prime} \mathrm{N}\right.$, altitude $\left.150 \mathrm{~m}\right)$. Three trees each of the early-ripening strains "Abe" and "Endo", and the mid-ripening strain "Izumo" were used for the experiment. The tree growth of "Abe" was inferior to that of "Endo" and "Izumo". All trees were 14 years old in the first year of investigation (2003). Trees were cultivated as described previously (Mochida et al., 2007), and all trees were cultivated in the same field. The sprouting dates in Masuda city in 2003 were 23 March for "Endo" and "Izumo" and 26 March for "Abe". In 2006 sprouting occurred from 17 March for "Endo" and "Izumo", and 19 March for "Abe". The sprouting date for "Abe" was slightly delayed in both years as a result of sprouting disorders.

\subsection{Meteorological observations}

We measured temperature at the experimental site from January to April in 2003 and 2006 using a thermocouple (T-type) located $1.5 \mathrm{~m}$ above the ground. Data was recorded using a data logger (R7326B type, ADVANTEST Co., Ltd., Japan). Data on the precipitation and sunshine duration from August to November in 2002 and 2005 were extracted from AMEDAS data from the Masuda station, which is located $3 \mathrm{~km}$ away from the experimental site.

\subsection{Measurement of cold tolerance in February and March (2006)}

Cold tolerance in early spring was evaluated by electrolyte leakage. Five 20 -cm twigs (branches that bore fruits in the previous year) each of "Abe", "Endo" and "Izumo" were collected on 21 February and 19 March, 2006 (bud sprouting period), and divided into five series (one of which served as the control). They were placed in plastic bags in a programmed freezer at a temperature below freezing. On 21 February, the temperature in the four series was reduced from +5 to $-5,-10,-15$, or $-20^{\circ} \mathrm{C}$ respectively. On 19 March the temperature was reduced from +5 to $-3,-6,-9$, or $-12^{\circ} \mathrm{C}$. The temperature was decreased within a period of $5 \mathrm{~h}$ for each series. The final temperature of each series was maintained for $5 \mathrm{~h}$, and then returned to $+5^{\circ} \mathrm{C}$ over $5 \mathrm{~h}$ (Leng et al., 1993). Each cold treatment had five replicates.

After the following $0^{\circ} \mathrm{C}$ treatments, 1-year-old twigs were cut into $5 \mathrm{~cm}$ stem portions, and the finely sliced $5 \mathrm{~g}$ samples (buds; $0.5 \mathrm{~g}$ ) were soaked in $40 \mathrm{~mL}$ of water at $20^{\circ} \mathrm{C}$ for $10 \mathrm{~h}$. The initial electric conductance $\left(C_{1}\right)$ was measured with a conductivity gauge (Horiba, C-173, Japan), while the second electric conductance $\left(C_{2}\right)$ was measured after the sample was killed in boiling water for $30 \mathrm{~min}$ and soaked in $40 \mathrm{~mL}$ water at room temperature for $12 \mathrm{~h}$. The electrolyte leakage (E) was calculated as follows; $E=C_{1} / C_{2} \times 100$. Three buds and 1-year-old stems were chosen from every tree after each sub-zero temperature treatment on 19 March. Each sample was dissected longitudinally through the centerline of the bud and stem, and evaluated for injury on the cut surface on the bud, cambium, xylem, and pith tissues of the stem. The degree of browning was classified as visual evidence of injury based on the following scale: 0 , no browning; 1 , slight browning; and 2 , severe browning.

\subsection{Determination of the carbohydrate content of stems and buds during the bud sprouting period (2003)}

The carbohydrate contents were determined in early spring. Five mature 1-year-old twigs (branches that bore fruit in the previous year) were collected from the central canopy of three trees, each of "Abe", "Endo" and "Izumo" strains. Twigs were collected on 26 March, 2003 and separated into buds and stem portions of approximately $5 \mathrm{~cm}$. The stems were cut into lengths of approximately $5 \mathrm{~mm}$. Stem pieces and buds were dried at $90^{\circ} \mathrm{C}$ for 10 days, and then ground using a masticator (WB-1, Osaka Chemical Co., Ltd., Japan). Dried samples (500 mg stems or $200 \mathrm{mg}$ buds) were placed into test tubes, and $30 \mathrm{~mL} 80 \%$ ethanol was added. The samples were then boiled at $80^{\circ} \mathrm{C}$ in a water bath for $30 \mathrm{~min}$, and then centrifuged. Each sample was extracted twice with $80 \%$ ethanol, and the combined ethanol extracts were evaporated with a rotary evaporator at $40^{\circ} \mathrm{C}$ to the water phase under reduced pressure. The water phases were diluted to an adequate concentration for HPLC analysis with the addition of distilled water, and filtered through a $0.45 \mu \mathrm{m}$ membrane filter. Sucrose, fructose, glucose, and sorbitol were measured by HPLC (Waters; RI 
detector; Sugar-Pak column; $\mathrm{H}_{2} \mathrm{O}$ elution solvent; column temperature $80^{\circ} \mathrm{C}$; flow rate $1 \mathrm{~mL} / \mathrm{min}$ ). The residues were then dried for starch determinations. To determine the starch content, $200 \mathrm{mg}$ dried samples of stems and $100 \mathrm{mg}$ dried samples of buds were placed into test tubes, and extracted three times with 8.14 $\mathrm{N} \mathrm{HClO}_{4}$. The extracts were then diluted to $100 \mathrm{~mL}$ with distilled water and the starch contents determined using by the Phenol- $\mathrm{H}_{2} \mathrm{SO}_{4}$ test (Sakano, 1989). The total carbohydrate contents were expressed in the form of the total of soluble sugars and starch. All analyses were replicated twice.

\subsection{Determination of non-tannin flavans (mainly anthocyanins) in stems and buds in February (2006)}

To clarify the non-tannin flavans (non-tannin flavonoids, mainly anthocyanins) in buds and stems, five 1-year-old twigs were collected from the central canopy of three trees each of "Abe", "Endo" and "Izumo" on 3 February, 2006. Twigs were separated into buds and stems, while the stem tissues were separated into bark and wood. The fresh tissues (bark and wood, $1.0 \mathrm{~g}$; bud, $0.5 \mathrm{~g}$ ) were ground using a masticator, mixed with $25 \mathrm{~mL} 80 \% \mathrm{MeOH}$, and kept at $4^{\circ} \mathrm{C}$ for $24 \mathrm{~h}$. The macerated mixture was then filtered and the residue re-extracted with $25 \mathrm{~mL} 80 \% \mathrm{MeOH}$. The combined methanol extracts were subsequently evaporated on a rotary evaporator at $40^{\circ} \mathrm{C}$ to the water phase under reduced pressure, and the water phase was fractionated with an equal volume of petroleum ether to remove lipids. The water phase was brought up to $50 \mathrm{~mL}$ for wood and bud tissues and $100 \mathrm{~mL}$ for bark tissues with distilled water, while non-tannin flavans were assayed by the partitioning of these crude extracts according to the modified method of Peri and Pompei (1971)
(Ito et al., 1987). Extractions were replicated three times. The supernatants (A) of the reaction mixtures of cinchonine sulfate and these crude extracts were insolubilized by adding formaldehyde under acid conditions. These precipitations were the non-tannin flavan fractions, while the supernatants (B) were simple phenols. Phenolics were determined in supernatants (A) and (B) using the modified Folin-Denis method (Swain and Hillis, 1959), with D-catechin used as the standard. The concentration of non-tannin flavans were calculated by subtracting B from A.

\section{Results}

\subsection{Meteorological observations}

Total precipitation was $348 \mathrm{~mm}$ from August to November in 2002, and $382 \mathrm{~mm}$ during the same period in 2005. Precipitation during this period in a normal year is $545 \mathrm{~mm}$. There were $697 \mathrm{~h}$ hours of sunshine in 2002, and $622 \mathrm{~h}$ in 2005 (620 h in a normal year) in Masuda. The minimum temperature every 5 days (extreme value) is shown in Fig. 1. Sub-zero temperatures occurred several times in the field during January to March in 2003 and 2006.

\subsection{Cold tolerance of stems and buds in February and March (2006)}

The electrolyte leakages $(E)$ of 1-year-old stems and buds of "Abe", "Endo" and "Izumo" subjected to sub-zero temperature treatments in winter and at the sprouting period are shown in Fig. 2. On 21 February, following the $-10^{\circ} \mathrm{C}$ treatment, the electrolyte leakage in stems of the three strains ranged from 13.0 to $14.4 \%$, and 17.2 to $24.3 \%$ in buds. On 19 March, following the $-9^{\circ} \mathrm{C}$ treatment, $E$ values ranged from 19.2 to $26.2 \%$, and 37.2 to $45.4 \%$ in stems and buds, respectively. Therefore, the electrolyte leakage was higher in March

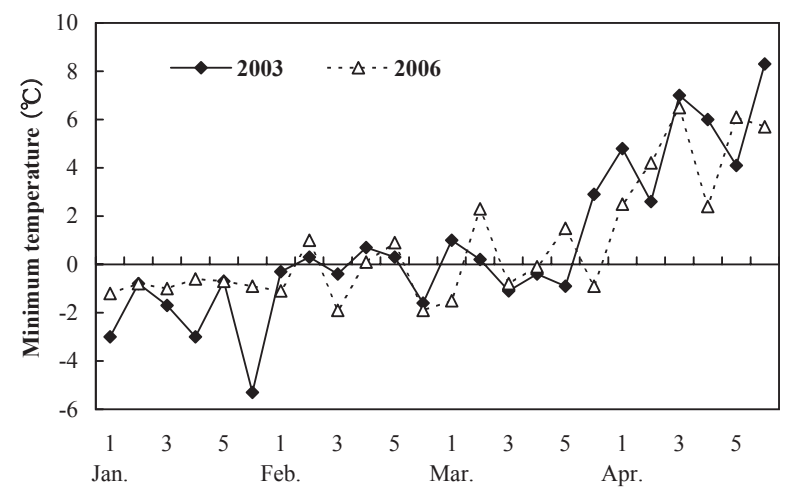

Fig. 1. Changes in minimun temperature every 5 days (extreme value) from Jan. to Apr. in 2003 and 2006. 

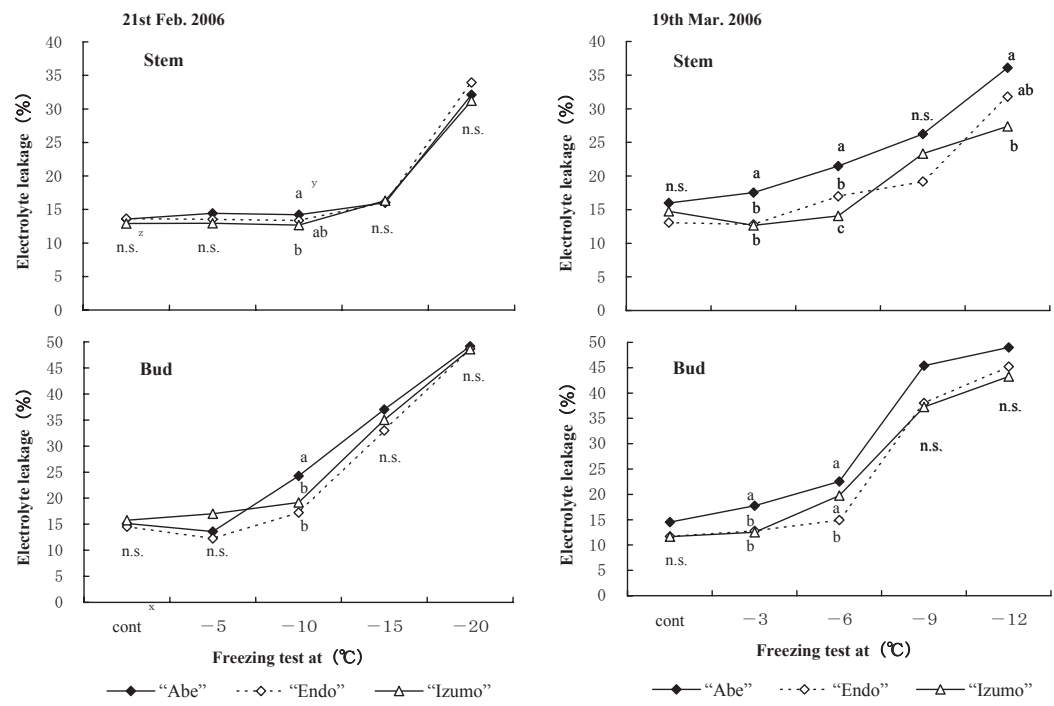

Fig. 2. Freezing resistance in stems and buds of 1-year-old twigs of three 'Saijo' strains in early, spring (21 Feb. and 19 Mar., 2006)

Freezing tolerance expressed as percentage electrolyte leakage from stems and buds respectively, after freezing tests at $-5,-10,-15$, and $-20^{\circ} \mathrm{C}$ on $21 \mathrm{Feb} 2006$, and at $-3,-6,-9,-12^{\circ} \mathrm{C}$ on 19 March, 2006.

${ }^{z}$ No significant differences among three strains (ANOVA).

y Strains with different letters in the same freezing test differ significantly (5\% level; Tukey test).

${ }^{x}$ Percentage electrolyte leakage from stems and buds at room temperature.

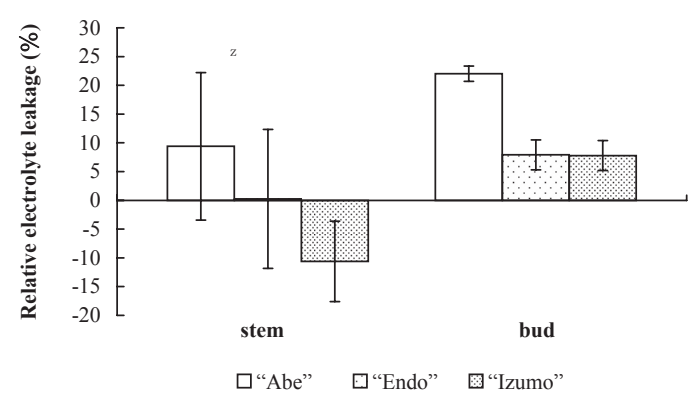

Fig. 3. Relative electrolyte leakage in stems and buds of 1-year-old twigs of three 'Saijo' strains after $-3^{\circ} \mathrm{C}$ treatment, compared to that at room temperature (19 March, 2006).

${ }^{z}$ Vertical bars indicate standard errors $(n=3)$.

than in February, and higher in buds than in stems. On 19 March, the electrolyte leakages of stems and buds in "Abe" at $-3^{\circ} \mathrm{C}$ were 17.5 and $17.8 \%$, respectively. These values were significantly higher than those of "Endo" and "Izumo".

The relative electrolyte leakage of stems and buds subjected to the $-3^{\circ} \mathrm{C}$ treatment compared with those at room temperature (control) on 19 March is shown in Fig. 3. The relative electrolyte leakage of stems in "Abe" was $9.4 \%$, which was relatively higher than that of other strains, although the difference was not significant. On the other hand, the relative electrolyte leakage of buds in "Abe" was $22.0 \%$, which was significantly higher than the relative E values of "Endo" and "Izumo".

The browning of 1-year-old stem and bud tissues after sub-zero temperature treatments is shown in Fig. 4. Slight browning was observed on the buds of "Abe" following the $-3^{\circ} \mathrm{C}$ treatment, while the browning level at $-6^{\circ} \mathrm{C}$ was 1 , and that at -9 and $-12^{\circ} \mathrm{C}$ in all samples was 2 respectively. The total browning of all samples at the lower temperatures meant that no difference emerged among the three strains. No browning was observed on the cambium in "Endo" and "Izumo" at $-6^{\circ} \mathrm{C}$ treatment. However, the browning level in "Abe" was approximately 0.6 , with slight visible injury. The browning levels at $-9^{\circ} \mathrm{C}$ in "Abe" and "Izumo" were approximately 1 , as opposed to approximately 0.6 in "Endo", which was relatively lower than the other two strains. Slight injury was evident in the woody tissues of "Abe" at $-9^{\circ} \mathrm{C}$ treatment, while only slight browning was observed on the wood in "Endo" and "Izumo" 

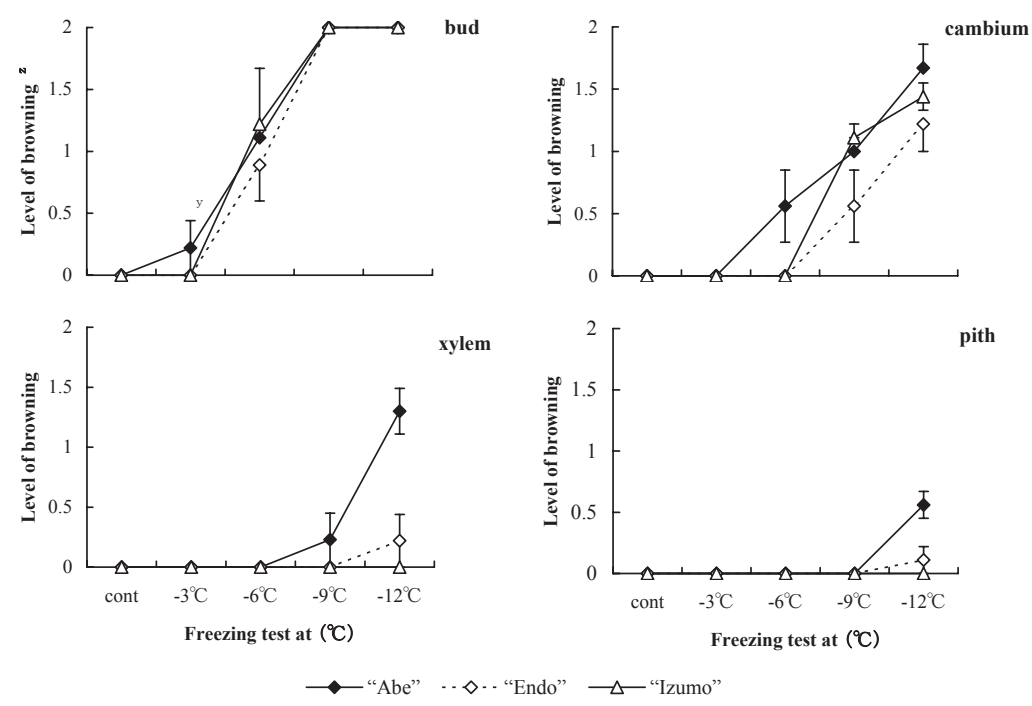

Fig. 4. Browning on stems and buds of 1-year-old twigs of three 'Saijo' strains after freezing tests at $-3,-6$, -9 , and $-12^{\circ} \mathrm{C}$ (19 March, 2006).

${ }^{\mathrm{z}}$ Browning was used as visual evidence of injury $(0=$ no browning, $1=$ slight browning, $2=$ severe browning).

${ }^{y}$ Vertical bars indicate standard errors $(n=3)$.

following the $-12^{\circ} \mathrm{C}$ treatment. Severe freezing injury occurred in "Abe" wood, with a browning level of approximately 1.3 . The browning level on the pith at $-12^{\circ} \mathrm{C}$ in "Abe" was approximately 0.6 , which was more severe than that shown by the other two strains.

\subsection{Carbohydrate content of stems and buds during the bud sprouting period (2003)}

Table 1 shows the starch and the sugar components in 1-year-old stems and buds of each strain at the bud sprouting period in 2003. Total sugar contents in 1-year-old stems of "Abe" were significantly lower than those of other strains, while no significant difference emerged in the starch contents of 1-year-old stems among the strains. In all strains, sucrose was the most abundant sugar in 1-year-old stems, followed by fructose, glucose, and sorbitol, while the sucrose and sorbitol contents in 1-year-old stems of "Abe" were significantly lower than the other two strains. Although no significant difference emerged among the strains, sugar contents in the bud of "Abe" tended to be lower than those of the other two strains, while the glucose content in the buds of "Abe" was significantly lower

Table. 1. Reserve carbohydrate contents in stems and buds of 1-year-old twigs of three strains of 'Saijo' persimmons (measured on 26 March 2003)

\begin{tabular}{|c|c|c|c|c|c|c|c|}
\hline \multirow[b]{2}{*}{ Portion } & \multirow[b]{2}{*}{ Strain } & \multirow[b]{2}{*}{$\begin{array}{c}\text { Starch } \\
\text { (\%. DW) }\end{array}$} & \multirow[b]{2}{*}{$\begin{array}{l}\text { Total sugar } \\
\text { (\%. DW) }\end{array}$} & \multicolumn{4}{|c|}{ composition of soluble sugar } \\
\hline & & & & $\begin{array}{l}\text { Sucrose } \\
\text { (\%. DW) }\end{array}$ & $\begin{array}{l}\text { Glucose } \\
\text { (\%. DW) }\end{array}$ & $\begin{array}{l}\text { Fructose } \\
\text { (\%. DW) }\end{array}$ & $\begin{array}{l}\text { Sorbitol } \\
\text { (\%. DW) }\end{array}$ \\
\hline \multirow{3}{*}{ stem } & "Abe" & 3.81 & $1.44 \mathrm{~b}^{\mathrm{z}}$ & $0.91 \mathrm{~b}$ & 0.20 & 0.29 & $0.03 \mathrm{~b}$ \\
\hline & "Endo" & 3.68 & $1.84 \mathrm{a}$ & $1.24 \mathrm{a}$ & 0.25 & 0.29 & $0.06 \mathrm{a}$ \\
\hline & "Izumo" & 3.61 & $1.68 \mathrm{a}$ & $1.12 \mathrm{a}$ & 0.18 & 0.29 & $0.08 \mathrm{a}$ \\
\hline \multirow[t]{2}{*}{ Significance $^{y}$} & & n.s. & $*$ & $*$ & n.s. & n.s. & $*$ \\
\hline & "Abe" & 3.04 & 2.74 & 1.97 & $0.41 \mathrm{~b}$ & 0.36 & 0.01 \\
\hline \multirow[t]{2}{*}{ bud } & "Endo" & 2.94 & 3.10 & 2.18 & $0.64 \mathrm{a}$ & 0.27 & 0.00 \\
\hline & "Izumo" & 3.20 & 2.93 & 2.02 & $0.67 \mathrm{a}$ & 0.23 & 0.01 \\
\hline Significance & & n.s. & n.s. & n.s. & * & n.s. & n.s. \\
\hline
\end{tabular}

${ }^{z}$ Different letters within column indicate significance at 5\% level (Tukey test).

$\mathrm{y} *$ Indicates significance at $5 \%$ level, n.s. indicates non-significance (ANOVA). 


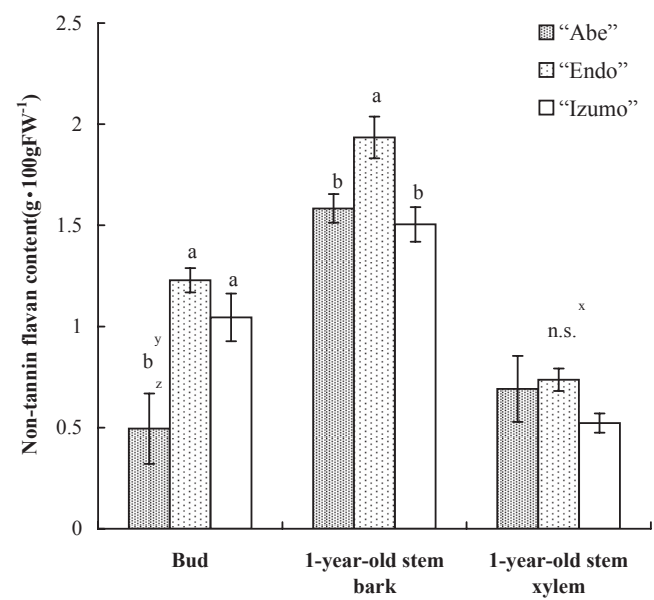

Fig. 5. Non-tannin flavan contents in xylem, bark, and bud tissues of three 'Saijo' persimmon strains. ${ }^{z}$ Vertical bars indicate standard errors $(n=3)$.

${ }^{y}$ Different letters within column indicate significance at 5\% level (Tukey test).

${ }^{x}$ No significant differences among three strains (ANOVA).

than those of the other two strains.

\subsection{Non-tannin flavans (mainly anthocyanins) in stems and buds in February 2006}

Non-tannin flavans (mainly anthocyanins) in the bark and wood tissues of 1-year-old stems and buds are shown in Fig. 5. The non-tannin flavan contents peaked in the bark, and were lower in the bud and wood. Although no significant difference emerged in the non-tannin flavan contents of wood tissue among the three strains, the non-tannin flavan contents in the bud and bark of "Endo" were higher than those of the other two strains. In particular, the non-tannin flavan contents in the buds of "Abe" were significantly lower than those of the other two strains.

\section{Discussion}

From autumn to winter in 2002 and 2005, the hours of sunshine fell within the normal range, but there was less precipitation than normal. Each strain produced a heavy crop (data not shown). Accordingly, there were presumably small amounts of reserve nutrients in buds and stems before sprouting in both 2003 and 2006. The low nutrient levels made these persimmon strains particularly susceptible to frost injury in 2003 and 2006, hence, these years were considered suitable times to clarify differences in cold tolerance among the strains.

The electrolyte leakage in the $-3^{\circ} \mathrm{C}$ treatment in "Abe" during the bud sprouting period was significantly higher than the E values of "Endo" and "Izumo". In particular, the relative electrolyte leakage from "Abe" buds in the $-3^{\circ} \mathrm{C}$ treatment compared to unfrozen controls was significantly higher than those from the other two strains (Figs. 2, 3), and slight browning was observed on the bud tissues (Fig. 4).

In the field, the intact buds and stems show frost injury at $-3^{\circ} \mathrm{C}$ during the bud sprouting periods (Kikuchi, 1991). As the electrolyte leakage at $-3^{\circ} \mathrm{C}$ exceeded that of the control, the cell membrane appeared to have been damaged. However, the $-3^{\circ} \mathrm{C}$ treatment was non-lethal to the buds and stems during the laboratory experiment in this study. In our experiment, 1-year-old stems and buds were not humidified before the sub-zero treatment. The temperature at which cold injury occurred was considered to be lower than that under natural conditions. Moreover, experimental conditions in a laboratory cannot exactly replicate natural conditions, because the rate of temperature change and the duration of the target temperature in nature are highly variable. Despite these limitations, our results show clear differences in cold tolerance among the three persimmon strains.

According to Leng et al. (1995), the temperature at which $50 \%$ survival occurs $\left(L T_{50}\right)$ corresponds to $25 \%$ electrolyte leakage. In late-February, $L T_{50}$ values in the three strains were about $-17^{\circ} \mathrm{C}$ to $-18^{\circ} \mathrm{C}$ in 1-year-old stems, and $-10^{\circ} \mathrm{C}$ to $-13^{\circ} \mathrm{C}$ in buds. However, in mid-March, the $L T_{50}$ values in stems of "Abe" were approximately $-8^{\circ} \mathrm{C}$ and $-12.5^{\circ} \mathrm{C}$ in both "Endo" and "Izumo", in contrast to $L T_{50}$ values in buds of -6.0 to $-6.5^{\circ} \mathrm{C}$ in "Abe", and -6.5 to $-7.0^{\circ} \mathrm{C}$ in both "Endo" and "Izumo". The cold tolerance of buds was lower in comparison to stems in both stages.

In early to late March, the minimum temperature at persimmon orchards in Shimane prefecture occasionally drops below zero. Slight late frost damage occasionally occurs in orchards near the experimental site. For example, the buds of a 'Saijo' strain (exact strain unclear) showed browning on 1 April, 2001 in orchards located in valleys in Masuda city. In these valley areas, the cold conditions persist remain for longer than at other more open sites. In 2006, sub-zero temperatures occurred four times in March at our site, meaning these sub-zero temperatures may have caused slight injury to the least tolerant strain 
of "Abe", which may result in decreased yields due to inhibited tree growth.

Sakai and Yoshida (1968) reported that an increased concentration of sugars and sugar-alcohols in plant tissues correlated with increased cold tolerance. The sugar contents of 1-year-old "Abe" stems were significantly lower than those of other strains and a similar pattern was observed in buds. Glucose contents, which affect susceptibility to freezing injury (Sakai and Yoshida, 1968), were significantly lower in buds of "Abe" than in the other two strains (Table 1). This suggests that low glucose content in the buds and low total sugar content in the 1-year-old stems of "Abe" was one of the reasons for vulnerability to freezing injury at sprouting.

The non-tannin flavan (mainly anthocyanins) content in buds of "Abe" was significantly lower than that in buds of "Endo" and "Izumo" (Fig. 5). Plant shoots accumulate anthocyanidin glycosides (anthocyanin) in vacuoles of epidermal and sub-epidermal cells, which turn red when they are subjected to low temperatures (Leng et al., 2000). An increased anthocyanin concentration in deciduous plants enhances cold tolerance. Anthocyanins accumulated in vacuoles may protect the vacuole membrane from low temperature injury (Leng et al., 2000). In fact, in Hedera helix L. leaves (Parker, 1962), and shoots of apple, peach (Leng et al., 2000) and persimmon (Leng et al., 1993), cold tolerance increased sharply in November and December, accompanied by a similarly sharp increase in anthocyanin concentration. As flavonoid compounds always exist as glycosides in plant tissues (Van Buren, 1970), the formation of non-tannin flavan glycosides (mainly anthocyanins) is thought to be largely influenced by sugar content. Miura and Iwata (1985) reported that the promotion of anthocyanin synthesis in Polygonum seedlings appeared to be closely correlated with the accumulation of carbohydrates, especially total sugars. The glucose content in "Abe" buds was markedly lower than that in the other two strains; therefore the formation of non-tannin flavan glycosides is assumed to be lower. This low concentration of sugars and flavan glycosides in "Abe" may enhance the freezing injury.

Matsumoto et al. (2006) suggested that sprouting disorders in 'Saijo' persimmon, such as suppressed or delayed sprouting, were exacerbated by sub-zero temperatures in winter, while Mochida et al. (2007) reported that among the early ripening "B-type" strains of 'Saijo', sprouting disorders were most common in "Abe". This study strongly suggests that the sprouting disorder in "Abe" was caused by non-lethal freezing injury to buds at temperatures below $0^{\circ} \mathrm{C}$ during sprouting, which may lead to a decreased leaf count and shorter stems. Unfortunately, "Abe" is likely to be already planted widely throughout Shimane prefecture.

It is probable that "Abe" will not recover from its sprouting disorders. The carbohydrate contents in buds and stems, and flavonoid contents in buds will decrease due to the decline in tree growth, which will trigger another late frost injury. As Matsumoto et al. (2006) pointed out, abnormally accumulated condensed tannins in the xylem suppressed the rising of the breeding sap. In turn, this obstructed water and mineral movement, ultimately causing the entire system to deteriorate. We confirmed that there were higher concentrations of tannins and $\mathrm{Ca}, \mathrm{Mg}$, and $\mathrm{Mn}$ in browned parts of the xylem of older woody tissue than in other healthy parts of the xylem (data not shown). In future, the selection of superior strains with respect to cold tolerance could be effective in reducing late frost injury and sprouting disorders in early strains of the 'Saijo' persimmon.

\section{References}

Isoda, R., 1983: Difference of fruit shape and quality in 'Saijo' Japanese persimmon. Res. Rep. of Hiroshima Agr. Coll., 7, 165-180 (In Japanese with English summary).

Ito, S., Matsuo, T., Ibushi, Y. and Tamari , N., 1987: Seasonal changes in the levels of polyphenols in guava fruit and leaves and some their properties. J. Japan. Soc. Hort. Sci., 56, 107-113 (In Japanese with English summary).

Kikuchi, T., 1991. Pomology hand book. 15-16. Yokendo. Tokyo. (In Japanese).

Kono, Y., Ito, T. and Azukizawa, A., 1980: Studies on selection of strains in 'Saijo' persimmons. (1) fruit shape of 'Saijo' in Shimane. Res. Rep. of Shimane Agric. Experi. Stat., 16, 56-68 (In Japanese).

Leng, P., 1995: Development of freezing tolerance and phenolic metabolism in persimmons. Tottori University dissertation, 3-19.

Leng, P., Itamura, H. and Yamamura, H., 1993: Freezing tolerance of several Diospyros species and Kaki cultivars as related to anthocyanin formation. $J$. Japan. Soc. Hort. Sci., 61, 795-804 (In Japanese 
with English summary).

Leng, P., Itamura, H., Yamamura, H. and Deng, X.M., 2000: Anthocyanin accumulation in apple and peach shoots during cold acclimation. Sci. Hort., 83, 43-50.

Leng, P., Okamori, T., Itamura, H. and Yamamura, H., 1997: Development of frost hardiness in Japanese persimmons. Acta Hort., 436, 109-118.

Matsumoto, T., Kurahashi, T., Yanagawa, T., Oyama, K., Maki, S. and Matsumoto, S., 2006: Physiological disorder of sprouting from dormant buds and the physiological mechanism in Japanese persimmon (Diospyros kaki Thunb.) 'Saijo'. Hort. Res. (Japan), 5(2), 129-133 (In Japanese with English summary).

Miura, H. and Iwata, M., 1985: Relation between anthocyanin and carbohydrate concentrations in seedlings of Benitade (Polygonum hydropiper L.). J. Japan. Soc. Hort. Sci., 54, 393-400 (In Japanese with English summary).

Mochida, K., Kurahashi, T. and Kono, Y., 2007: Selection of high-yielding strains in early-ripening typed
'Saijo' persimmon. Hort. Res. (Japan), 6(1), 105-111. (In Japanese with English summary).

Parker, J., 1962: Relationships among cold hardiness, water-soluble protein, anthocyanins, and free sugars in Hedera helix L. Plant Physiol., 37, 809-813.

Peri, C and Pompei, C., 1971: Estimation of different phenolic groups in vegetable extracts. Phytochemistry, 10, 2187-2189.

Sakai, A. and Yoshida, S., 1968: The role of sugar and related compounds in variations of freezing resistance. Cryobiology, 5, 160-174.

Sakano, Y., 1989: A method of experiment of starch and the relation sugar. Society Publishing Center. Tokyo, 44-45 (In Japanese).

Swain, T. and Hillis, W. E., 1959: The phenolic constituents of Prunus Domestica L. I. The quantitative analysis of phenolic constituents. J. Sci. Food Agric., 10, 63-68.

Van Buren, J., 1970: The biochemistry of fruits and their products. 11. Fruit phenolics. Academic Press, London and New York, 276-280.

\title{
カキ ‘西条’における耐凍性の系統間評価
}

\author{
持田圭介** 板村裕之 $* *$ \\ $\left(\begin{array}{c}* \text { 島根県農業技術センター } \\ * * \text { 島根大学生物資源科学部 }\end{array}\right)$
}

要

約

“西条ににおる耐凍性の系統間差について, 早生 “B 型”系統の “安部”系および “遠藤”系と中晚生の “出雲型” 系統で比較した。各供試系統の 1 年生枝の枝部分およ び芽について, 炭水化物並びに非タンニンフラバン (主と してアントシアニン) 含量を測定した。“安部”系は，萌 芽前の枝中糖含量が “遠藤”系および “出雲型” 系統と 比較し有意に少なく, これはショ糖とソルビトール含量が 有意に少ないことが要因であった。また, 同時期の“安 部” 系の芽中ブドウ糖含量が, 他の 2 系統と比較し有意
に少なかった。芽および枝皮層部中非タンニンフラバン 含量は, “安部”系で少なく“遠藤”系で多かった。3 月 中旬の枝と芽の $-3^{\circ} \mathrm{C}$ おび $-6^{\circ} \mathrm{C}$ 処理後の電解質浸出率 は, “安部”系が有意に高く, 芽では $-3^{\circ} \mathrm{C} て ゙, 1$ 年生枝形 成層は $-6^{\circ} \mathrm{C}$ で褐変障害が認められ, “安部”系は他系統 より耐凍性が劣つた。“安部”系で多発している春季発芽 不良症状は, 芽に軽度の凍害を被ったことが一因と推察 された。 キーワード : アントシアニン, フラバン, 低温障害, 糖 